

\title{
The Recognition of Higher Education Diplomas and Qualifications
}

An overview of the legal framework and discussion of prevailing obstacles for "automatic" academic recognition from the perspective of German law

\section{By Dr. RenAte Penßel}

\begin{abstract}
The article provides an overview of the legal rules concerning the recognition of higher education diplomas and qualifications in international (including European) and German law. After an introduction to the legal framework (concerning recognition for the purpose of (self)employment on the one hand and concerning recognition for the purpose of further higher education at the other hand), it concentrates on current problems occurring in the field of recognition for the purpose of further education: It examines the transposition of the most relevant provisions in international law (i.e. the Lisbon Recognition Convention) to German national law. Afterward it illustrates the interpretation of those national provisions by German jurisdiction. A comparison between the guidelines given in international law and the application of the corresponding national provisins by the German courts reveals that current German jurisdiction does not live up to international law but contravenes its intentions.

Link to the original article: http://ordnungderwissenschaft.de/wpcontent/uploads/2020/03/05 Pen\%C3\%9Fel.pdf 02/2020 ODW <http://ordnungderwissenschaft.de/
\end{abstract}




\section{$\underline{\text { Table of contents }}$}

I. The main sources of law - an overview

1. Provisions concerning recognition for the purpose of further higher education (Academic Recognition)

a) European Union law

aa) Third country nationals

bb) EU citizens (and family members)

b) International law

2. Provisions concerning recognition for the purpose of (self-)employment (Professional Recognition)

a) European Union law

aa) EU citizens

bb) Third country nationals

b) International law

c) National law

II. Selective difficulties in the implementation of the rules concerning academic recognition from the perspective of German law

1. The implementation of the Lisbon Recognition Convention through regulations of the Länder and higher education institutions

2. Specification of recognition criteria in current jurisdiction

III. Conclusion 
One of the main aims of the Bologna process is to enhance the mobility of students and graduates across national borders. Therefore, the process is based on three key commitments: (1) the implementation of the three-cycle degree structure, (2) the recognition of qualifications and (3) quality assurance. The 2018 Report on the Implementation of the Bologna Process states that these three commitments "can be considered as the foundations of the European Higher Education Area (EHEA): if these foundations are not in place, further European higher education cooperation is undermined."1

Although these three commitments are obviously closely intertwined, this article will put its focus only on one of them: the recognition of higher education qualifications. Concerning this commitment, the Report explains that "the EHEA cannot be an open, inclusive and attractive space for students unless recognition practice is predictable, reliable and fair. For any mobile or potentially mobile learner, it is essential that credits earned and qualifications gained will be recognized in the home and other countries."2 And it states that " $(. .$.$) despite the many efforts made in this area, previous reporting$ has shown that actual recognition practice commonly falls short of expectations with regard to transparency, consistency and fairness"3.

Accordingly, the EHEA Ministerial Conference in Paris 2018 confirmed that it will "work to ensure that comparable higher education qualifications obtained in one EHEA country are automatically recognized on the same basis in the others for the purpose of accessing further studies and the labour market."4

These statements - together with current evaluations of recognition practice - illustrate that the desired "automatic recognition" is not reality yet.

Therefore this article will outline the status quo of legal rules concerning recognition in the EHEA, identify some selected problems with the implementation of these rules and finally try to conclude whether and how they can be solved. In doing so it will focus on problems occuring when recognition for the purpose of further studies is sought, because, as the following examination of the legal framework and an analysis of the current jurisdiction in Germany will illustrate, in this field hinderances for "automatic" or

\footnotetext{
${ }^{1}$ European Commission/EACEA/Eurydice (ed.), The European Higher Education Area in 2018: Bologna Process Implementation Report, 2018, p. 13.

${ }^{2}$ Bologna Process Implementation Report (fn. Fehler! Textmarke nicht definiert.), p. 142.

${ }^{3}$ Ibid.

${ }^{4}$ European Higher Education Area Ministerial Conference 2018, Paris Communiqué, 25th of May 2018, http://www.ehea.info/media.ehea.info/file/2018 Paris/77/1/EHEAParis2018 Communique final 952771.pdf (15.2.2020), p. 2. Therein the Ministerial Conference refers to the objective, formulated within the Yerevan Communiqué 2015,

http://ehea.info/media.ehea.info/file/2015 Yerevan/70/7/YerevanCommuniqueFinal 613707.pdf (15.2.2020), that „by 2020 (...) automatic recognition of qualifications (should have) become a reality“; s. also its commitment 11 ,to ensure that qualifications from other EHEA countries are automatically recognized at the same level as relevant domestic qualifications", p. 5.
} 
even generous recognition are still significant and even bigger than in at least some constellations in which recognition for the access to the labour market is sought.

For that purpose, the article will first (I.) give an overview of the current legal framework regulating the recognition of higher education qualifications by naming the most important legal sources and illustrating their main content. Second (II.), it will demonstrate some difficulties in the implementation of the rules concerning academic recognition from the perspective of German law. In a third and final step (III.) it will conclude whether it is possible to enhance academic recognition by correct application or better implementation of existing rules and whether additional measures are needed to reach the desired level of recognition.

\section{The main sources of law - an overview}

To identify the relevant legal sources, one has to distinguish between the two already mentioned different aims of recognition of higher education qualifications: between the recognition for the purpose of further higher education (which shall from now on be abbreviated as "academic recognition") and the recognition for the access to employment activity (which shall from now on be called "professional recognition").

\section{Provisions concerning recognition for the purpose of further higher education (Academic Recognition)}

Let us first have a look at the provisions concerning recognition for the purpose of further higher education:

a) European Union law

In EU primary law we can find two articles that explicitly deal with the recognition of higher education qualifications. One of them is Art. 53 TFEU. It is part of the chapter dedicated to the freedom of establishment but is according to Art. 62 TFEU also applicable for the chapter concerning the freedom of services. It enables Parliament and Council to issue directives for the mutual recognition of qualifications in order to make it easier for people to take up and pursue activities as self-employed persons. Art. 53 TFEU can thus only be used as a legal basis for provisions that deal with recognition for the purpose of self-employment. Acts on academic recognition cannot be based on it. The same applies to the corresponding provision within the chapter concerning the free movement of workers, Art. 46 TFEU.

The other article that explicitly deals with the issue of recognition of qualifications is Art. 165 TFEU 5 : According to paragraph 2, the Union shall aim at "encouraging mobility

\footnotetext{
${ }^{5}$ The author follows those who argue that for activities in the field of (regular, i.e. not extra-occupational) higher education Art. 165, not Art. 166 TFEU, is pertinent (see e.g. Ruffert, in: Calliess/Ruffert (eds.), EUV/AEUV, 5th ed., 2016, comment 12 seq. with further references concerning this dispute, also to the opposite view).
} 
of students and teachers, by encouraging, inter alia, the academic recognition of diplomas and periods of study". For systematic reasons, all activities based on Art. 165 paragraph 2 must respect the restriction formulated in paragraph 1, which states that the EU is only allowed to encourage cooperation between its Member States and to support and supplement their action while fully respecting the responsibility of the Member States for the content of teaching and the organization of education systems. Therefore, and due to the limitation explicitly formulated in its paragraph 4 Art. 165 TFEU cannot be the basis for any kind of directly harmonizing acts ${ }^{6}$ and requires strict subsidiarity ${ }^{7}$.

So far, the EU has also not used other, more general legal bases for directives on recognition. Although proposed in legal scholarship 8 up to now the EU has abstained from issuing directives on the basis of Art. 115 TFEU $^{9}$. The use of the extraordinary competence provided in Art. 352 TFEU is excluded through its paragraph 4 in conjunction with Art. 165 paragraph 4 TFEU.

Obviously the Member States opted to achieve better cooperation through soft law instruments or promotional programs (like the Erasmus+ Program) rather than through compulsive rules. Therefore it can be concluded that EU legislation currently does not provide any criteria or procedural obligations for academic recognition.

However, European Union Law in certain respect provides - as is generally known the right to equal treatment:

\section{aa) Third country nationals}

At first we will have a look at the rights of third country nationals because a provision dedicated to them explicitly mentions recognition of qualifications:

According to Art. 11 Directive 2003/109/EC (the so called "Long-term-Residence Directive"10) third country nationals with the right to long-term residence in an EU

\footnotetext{
${ }^{6}$ See also e.g. Niedobitek, in: Streinz (ed.), EUV/AEUV, 3rd ed., 2020, Art. 165 comment 61; Ruffert, in: Calliess/Ruffert (eds.), EUV/AEUV, 5th ed., 2016, comment 22.

${ }^{7}$ In this respect it would not make a difference if in matters of higher education Art. 166 instead of Art. 165 TFEU would be the appropriate provision: Art. 166 TFEU also limits the competence of the EU to "support" and "supplement" (see paragraph 1) and excludes any harmonization of the laws and regulations of the Member States.

${ }^{8}$ Garben, The Bologna Process: From a European Law perspective, European Law Journal, Vol. 16, No. 2, 2010, pp. 186 (193 seq.); referred in Gideon, The position of higher education institutions in a changing European context, JCMS 2015, Vol. 53, No. 5, pp. 1045 (1047).

${ }^{9}$ It is doubtful whether this would be lawful, because those measures based on Art. 115 TFEU would undermine the restrictions formulated in Art. 165 I, IV TFEU. Whereas Garben, The Bologna Process (fn. Fehler! Textmarke nicht definiert.), pp. 193 seq. argues against an interpretation of Art. 165 IV TFEU as an absolute limitation to harmonization, Hablitzel, Harmonisierungsverbot und Subsidiaritätsprinzip im europäischen Bildungsrecht, DÖV 2002, 407 (409) argues for it.

${ }^{10}$ Council Directive 2003/109/EC of the 25th of November 2003, OJ L 16, 23.1.2004, p. 44.
} 
Member State can require equal treatment with nationals of their host state in certain respects, among which the recognition of qualifications is explicitly mentioned. Yet, one has to keep in mind that the "Long-term-Residence Directive", according to its Article $3 \mathrm{II}$ a) does not apply to third country nationals that reside in their host state in order to pursue studies. Consequently in many cases, in which academic recognition is sought, Art. 11 of Directive 2003/109/EC will not be pertinent (but it is - at least according to its wording - applicable in cases, in which a third country national resides in a Member State for the purpose of employment, but aims to pursue studies additionally).

It can be discussed whether third country nationals can claim not to be discriminated by reason of nationality due to Art. 21 /I of the Charter on fundamental rights of the European Union (thereafter: EUChFR) ${ }^{11}$. Even if this would be the case, however, this provision is only binding on the institutions and bodies of the Union as well as on the Member States when implementing EU law (Art. 51 । 1 EUChFR). Because - as mentioned above - there is currently no EU law dealing with academic recognition for third country nationals (beside Art. 11 Long-term-Residence Directive), this provision is typically not applicable.

\section{bb) EU citizens (and family members)}

Although Art. 21 II EUChFR undoubtedly protects EU citizens its importance for them might be in effect not bigger than for third country nationals: as decisions on academic recognition are not determined by EU law at the moment, one can argue that the Member States thereby do not implement EU law, so Art. 21 II EUChFR is not applicable.

\footnotetext{
${ }^{11}$ Mostly it is argued that Art. 21 II EuChFR does not apply to third country nationals (see e.g. Hölscheidt, in: Meyer/Hölscheidt (eds.), Charta der Grundrechte der Europäischen Union, 5th ed., 2019, Art. 21, comment 60; Jarass, in: Jarass (ed.), Charta der Grundrechte der EU, 3rd ed., 2016, comment 42; Martin, in:

Kellerbauer/Klamert/Tomkin (eds.), The EU Treaties and the Charter of Fundamental Rights, 2019, Art. 21 ChFR comment 10, Art. 18 TFEU comment 3; von der Decken, in: Hesselhaus/Nowak (eds.), Handbuch der Europäischen Grundrechte, 2nd. ed., 2020, § 49 comment 41), as (according to Art. 52 II EUChFR) it has to be interpreted in the same sense as Art. 18 TFEU, which shall also only be applicable to EU citizens (see e.g. CJEU Case C-291/09 - Guarnieri; Martin, in: Kellerbauer/Klamert/Tomkin (eds.), The EU Treaties and the Charter of Fundamental Rights, 2019, Art. 18 comment 3; von der Decken, in: Hesselhaus/Nowak (eds.), Handbuch der Europäischen Grundrechte, 2nd ed. 2020, § 49 Rn. 19). Others argue that the character of Art. 21 II EUChFR as a fundamental right contravenes an absolute limitation on EU citizens, see Kugelmann, in: Merten/Papier (eds.), Handbuch der Grundrechte in Deutschland und Europa, Vol. VI/1, 2010, § 160 comment 52.
} 
Nevertheless EU citizens can demand not to be discriminated directly or indirectly ${ }^{12}$ by reason of nationality due to Art. 18 I TFEU. Art. 18 I TFEU is directly applicable ${ }^{13}$ as long as the situation falls within the scope of the treaty. As - what was mentioned before - Art. 165 TFEU allows the EU to encourage academic recognition and Art. 21 TFEU principally opens way to free movement of EU citizens within the Union the scope of application of the treaty is given whenever recognition across borders is sought $^{14}$.

A further and probably even more promising provision for EU citizens and - moreover - their third state national family members is Art. 24 of the Directive 2004/38/EC $C^{15}$ (the so called "Citizen's Rights Directive"; thereafter: CRD): It also provides the right of equal treatment and is applicable to all EU citizens residing in a foreign Member State, as long as their residence conforms to the regulations of the directive. If not transposed correctly into national law, Art. 24 I CRD has the potential to be directly effective ${ }^{16}$. The relation between Art. 18 TFEU and Art. 24 I Directive 2004/38/EC is not easy to define: According to the CJEU Art. 24 CRD can be understood as (lawful) specification of Art. 18 TFEU $^{17}$. It is therefore the crucial provision in cases in which EU citizens reside in

\footnotetext{
12 See e.g. CJEU Case C-147/03 - Commission vs. Austria, EuZW 2005, 465, para. 41; Epiney, in: Calliess/Ruffert (eds.), EUV/AEUV, 5th ed., 2016, Art. 18 comment 12; Martin, in: Kellerbauer/Klamert/Tomkin (eds.), The EU Treaties and the Charter of Fundamental Rights, 2019, Art. 18 TFEU comment 17; von der Decken, in: Hesselhaus/Nowak (eds.), Handbuch der Europäischen Grundrechte, 2nd ed., 2020, § 49 comment 26.

${ }^{13}$ Settled case law, see e.g. CJEU Case C-85/96 - Martinez Sala, para. 63; Case C-274/96 - Bickel und Franz, EU:C:1998:563; Epiney, in: Calliess/Ruffert (eds.), EUV/AEUV, 5th ed., 2016, Art. 18 Rn. 2; Martin, in: Kellerbauer/Klamert/Tomkin (eds.), The EU Treaties and the Charter of Fundamental Rights, 2019, Art. 18 TFEU comment 23; von der Decken, in: Hesselhaus/Nowak (eds.), Handbuch der Europäischen Grundrechte, 2nd ed. 2020, § 49 comment 16.

${ }^{14}$ The CJEU stated various times (see e.g. Case C-293/83 - Gravier, EU:C:1985:69; Case C-147/03 - Commission vs. Austria) that the conditions determining the access to professional education, including professional education at higher education institutions, fall into the ambit of the treaty. In his decision from the 1 . of July 2004 - C-65/03 para. 25 - the CJEU explicitly mentioned Art. 149 II dash 2 (the provision preceding Art. 165 II, which shared its wording) to argue that the scope of the Treaty is given. Furthermore according to several decisions of the CJEU (see e.g. Case C-274-96 - Bickel und Franz, EU:C:1998:563, para. 15; Case C-333/13, EU:C:2014:2358 = NVwZ 2015, 145, para. 58 - Dano) the relevance of the right of free movement conferred in Art. 21 TFEU is sufficient to constitute a situation governed by EU law (see also Martin, in:

Kellerbauer/Klamert/Tomkin (eds.), The EU Treaties and the Charter of Fundamental Rights, 2019, Art. 18 TFEU comment 13).

${ }^{15}$ Directive 2004/38/EC of the European Parliament and of the Council of the 29th of April 2004, OJ L 158, 30.4.2004, p. 77.

${ }^{16}$ Art. 24 I Directive 2004/38/EC meets all conditions the CJEU formulated for acknowledging a directive to be directly effective (to these conditions see e.g. Case C-282/10 Dominguez, EU:C:2012:33 para. 33 and the case law cited): a directive (which has not or not correctly been transposed into national law) is directly effective when it is "unconditional" and "sufficiently precise" (for more details see e.g. Klammert/Loewenthal, in: Kellerbauer/Klamert/Tomkin (eds.), The EU Treaties and the Charter of Fundamental Rights, 2019, Art. 288 comment 30-40).

${ }^{17}$ CJEU Case C-333/13 EU:C:2014:2358 = NVwZ 2015, 145 - Dano, para. 67-82; Case C-67/14 EU:C:2015:597 = NVwZ 2015, 1517; NJW 2016, 555 - Alimanovic, para. 48-63.
} 
a foreign Member State in accordance with the CRD ${ }^{18}$. Vice versa, the CJEU stated that a person residing in a foreign Member State against the provisions of the CRD can neither claim equal treatment from Art. 24 CDR nor from Art. 18 TFEU (because he or she does not act within the "scope of the treaty", which allows to limit free movement of EU citizens without economic purpose through secondary law, $\mathrm{cp}$. Art. 21 I TFEU) ${ }^{19}$. For petitioners that do not reside in a foreign Member State - so that Art. 24 CRD is not applicable - Art. 18 TFEU is decisive ${ }^{20}$.

b) International law

We will go on with a look at the legal sources that can be found in international law.

Although there is a big variety of international agreements and declarations dealing with the international recognition of higher education qualifications from the perspective of almost all EU Member States ${ }^{21}$ the by far most important agreement is the Convention on the Recognition of Qualifications concerning Higher Education in the European Region ${ }^{22}$, the so called Lisbon Recognition Convention. It was concluded in 1997 within the framework of the Council of Europe and the European Section of the UNESCO. After the fall of the Iron Curtain, facing an increase of international mobility, an increase of importance of tertiary education and also an increase of diversity therein, its authors aimed at replacing older recognition agreements which (at least the most important among them) dated back to the late $1950^{\text {th }}$ in order to facilitate student mobility to be able to meet the requirements of rising "globalisation"23. Up to now the Lisbon Recognition Convention has been ratified by 53 states and the Holy See, among others all Member States of the European Union (besides Greece), further member states of the Council of Europe like Switzerland, Norway or the Russian

\footnotetext{
18 In Case C-67/14 (= NVwZ 2015, 1517; NJW 2016, 555) - Alimanovic the CJEU pointed out, that a claimant residing in a foreign Member State in compliance with the provisions of the CRD can nevertheless be discriminated on the basis of Art. 24 II CRD. The CJEU did not discuss whether Art. 18 TFEU could hinder such discrimination: Obviously according to the CJEU Art. 18 TFEU is not opposed to secondary law like Art. 24 II CRD which explicitly permits discrimination of EU citizens within the scope of application of the treaty, because Art. 21 I TFEU allows to restrict the right of free movement through secondary law.

${ }^{19}$ Case C-333/13 (= NVwZ 2015, 145) - Dano; Case C-67/14 (= NVwZ 2015, 1517; NJW 2016, 555) - Alimanovic, para. 48-63. See also Epiney, in: Calliess/Ruffert (eds.), EUV/AEUV, 5th ed., 2016, Art. 18 Rn. 19.

${ }^{20}$ See CJEU Case C-274/96 - Bickel und Franz; Case C-322/13 - Grauel Rüffer: in these decisions the CJEU affirmed the violation of Art. 18 TFEU without reference to Art. 24 CRD; the petitioners in this cases did not reside in a foreign Member State.

${ }^{21}$ The conventions and declarations with relevance for Germany are collected and presented online by the "Conference of the Ministers for Cultural Affairs", see https://www.kmk.org/zab/zentralstelle-fuerauslaendisches-bildungswesen/allgemeines-zur-anerkennung/veroeffentlichungen-undbeschluesse/akademische-anerkennung.html (15.2.2020).

22 Signed in Lisbon on the 11th of April 1997, Council of Europe - European Treaty Series No. 165.

${ }^{23}$ Bergan/Rauhvergers, The Council of Europe/UNESCO (Lisbon) Recognition Convention - what it is and how to use it, in: Council of Europe (ed.), Standards for recognition: the Lisbon Recognition Convention and its subsidiary texts, 2005, p. 8; Hochschulrektorenkonferenz (ed.), Anerkennung von im Ausland erworbenen Studien- und Prüfungsleistungen - Ein Leitfaden für Hochschulen, 2013, https://www.hrknexus.de/uploads/media/nexus Leitfaden Anerkennung Lang 01.pdf(15.2.2020), p. 9.
} 
Federation, and even states outside Europe such as Canada, Australia or New Zealand 24 .

Although several parties of the Lisbon Recognition Convention have also signed more favourable bilateral recognition agreements with other states (e.g. Germany with France ${ }^{25}$ or Spain $\left.{ }^{26}\right)^{27}$ and there also exist numerous recognition agreements concluded with states that are not parties of the Lisbon Recognition Convention, most of the cases in practice are covered by the Lisbon Recognition Convention: With 54 parties all over and outside Europe this agreement has definitely the widest scope. Therefore this article will concentrate on the provisions and on the implementation of this treaty and leave other treaties aside.

The Lisbon Recognition Convention deals with the recognition of "qualifications giving access to higher education" (which shall not be the topic of this article), of "periods of studies", which means qualifications obtained within a course of study, and "qualifications", which the convention defines as certificate attesting the successful completion of a course of study. This article will concern both: qualifications obtained within a course of study and qualifications obtained through completion of a course of study, because both of them are relevant for student mobility, and at least in practice the problems with recognition of "periods of study" are even bigger than those caused by the recognition of final "qualifications".

The key provision in the Lisbon Recognition Convention for the recognition of higher education "qualifications" is Art. VI. 1. It states that "to the extent that a recognition decision is based on the knowledge and skills certified by the higher education qualification, each Party shall recognize the higher education qualifications conferred in another Party, unless a substantial difference can be shown between the qualification for which recognition is sought and the corresponding qualification in the Party in which recognition is sought." Art. V.1. applies the same scale to the recognition

\footnotetext{
${ }^{24}$ Germany signed the Lisbon Recognition Convention on the 11th of April 1997. It was transformed into national law by the Statue concerning the Convention on the recognition of qualifications concerning higher education in the European region from the 16th of May 2007. This statute and the wording of the Lisbon Recognition Convention in English, French and German is published in: BGBI. 2007, part II no. 15, pp. 712-732. An updated list of signatures and ratifications is presented on the website of the Council of Europe: https://www.coe.int/en/web/conventions/full-list/-/conventions/treaty/165 (15.2.2020).

25 „Abkommen zwischen der Regierung der Bundesrepublik Deutschland und der Regierung der Französischen Republik über die Anerkennung von Abschlüssen, Graden und Studienzeiten im Hochschulbereich " of the 31th of March2015, BGBI. 2016, part 2 no. 3, pp. 124-126 (Agreement between Germany and France concerning the recognition of degrees, grades and periods of study in the field of higher education).

${ }^{26}$ „Abkommen zwischen der Regierung der Bundesrepublik Deutschland und der Regierung des Königreichs Spanien über die Anerkennung von Gleichwertigkeiten im Hochschulbereich" of the 14th of November 1994, BGBI. 1996, part. 2 no. 12, pp. 332-333 (Agreement between Germany and Spain concerning the recognition of equivalences in the field of higher education).

${ }^{27}$ Pursuant to Art. II.3 Lisbon Recognition Convention those provisions precede the Lisbon Recognition Convention.
} 
of "periods of study": it has to take place "unless substantial differences can be shown between the periods of study completed in another party and the part of the higher education program which they would replace". In comparison with former recognition agreements the Articles V.1 and VI.1 facilitate positive recognition decisions in two dimensions: While former agreements demanded recognition only in cases of "equivalence" of qualifications ${ }^{28}$ Art. V.1 and Art. VI.1 Lisbon Recognition Convention obviously aimed to establish a lower standard of conformity (which it calls: "lack of substantial differences") ${ }^{29}$ and addresses thereby not the examination itself, but the learning outcome ("knowledge and skills") certified through the formal qualification. And while according to former agreements the onus of presentation and the burden of proof (for equivalence) lay with the applicant, the Lisbon Recognition Convention obliges the parties to recognize a qualification unless the recognizing authority can demonstrate and prove a "substantial difference". Beyond that, the Convention tries to encourage recognition through various procedural rules. For example, it obliges the parties to provide that procedure and criteria for decisions on recognition are "transparent, coherent and reliable" (Art. III.2), that decisions are made within a reasonable time limit specified beforehand (Art. III.5) and that in case of a negative decision, the applicant has the right to lodge an appeal. Art. VI.3 defines the legal effect of recognition of "qualifications" in the sense of the Lisbon Recognition Convention: "Recognition in a Party of a higher education qualification issued in another Party shall have one or both of the following consequences: a) access to further higher education (...) on the same conditions as those applicable to holders of qualifications of the Party in which recognition is sought, (or) b) the use of an academic title, subject to the laws

\footnotetext{
${ }^{28}$ Among the treaties with persistent relevance for Germany see e.g. the European Convention on the Equivalence of Periods of Universtity Study, signed in Paris on the 15th of December 1956 (Council of Europe European Treaty Series Nr. 21), the European Convention on the General Equivalence of Periods of Study, signed in Rome on the 6th of November 1990 (Council of Europe - European Treaty Series Nr. 138) (which both preceded the regulations of Art. V Lisbon Recognition Convention) and the European Convention on the Academic Recognition of University Qualifications, signed in Paris on the 14th of December 1959 (Council of Europe - European Treaty Series Nr. 32) (which preceded the regulations of Art. VI Lisbon Recognition Convention).

${ }^{29}$ Actors in German Administration dealing with academic recognition share this interpretation (see e.g. Hochschulrektorenkonferenz (ed.), Anerkennung (fn. Fehler! Textmarke nicht definiert.), p. 14 and in particular chapter III: „Von der Gleichwertigkeit zum wesentlichen Unterschied“; see furthermore the Letter of the Head of the German Accreditation Council of the 27th of September 2011 concerning the implementation of the Lisbon Recognition Convention, Az. 233/11

http://archiv.akkreditierungsrat.de/fileadmin/Seiteninhalte/AR/Sonstige/AR Rundschreiben Lissabon1.pdf (15.2.2020): „Dabei (bei der Entscheidung über die Anerkennung, R.P.) liegt der Fokus der Bewertung der Hochschule nicht mehr auf der „Gleichwertigkeit“ oder „Gleichartigkeit“ der anzuerkennenden Qualifikation, sondern auf der Wesentlichkeit von Unterschieden. Da bei der Feststellung unwesentlicher Unterschiede die extern erbrachten Hochschulqualifikationen anerkannt werden (...) bringt dies einen größeren Spielraum als bisher"). Although the terms "equivalence" and "lack of substantial difference" could linguistically also be synonyms, the motifs which led to the conclusion of the Lisbon Recognition Convention indicate that they should stand for a different scale. It is not so easy to describe that difference in a way that makes it operable for legal descisions. However, the new terminology at least clarifies that recognition is not hindered through bigger differences as long as those differences are not "substantial ones".
} 
and regulations of the Party (...) in which recognition is sought. In addition, recognition may facilitate access to the labour market subject to laws and regulations of the Party (...) in which recognition is sought." From that, we can see that the Lisbon Recognition Convention is dedicated to academic recognition and does not impose obligations on its parties concerning professional recognition.

Since the Lisbon Recognition Convention being an instrument of international law, we have to answer the question what legal effects its provisions have after fulfilling the constitutional conditions of the ratifying states to set them into force within their national law (if there are such). The question is not easy to answer. Obviously different views on that can be even found within, for example, the German jurisdiction: while some German courts decided cases within the scope of the Lisbon Recognition Convention without mentioning $\mathrm{it}^{30}$ in other decisions provisions of the Lisbon Recognition Convention are explicitly mentioned and treated as directly applicable law ${ }^{31}$.

A closer look at the key provisions of the Lisbon Recognition Convention reveals that they are not applicable without being specified by the parties. Although the conditions for recognition formulated in Art. VI.1 could be perceived to be precise enough for direct application, Art. VI.3 of the Convention opens a margin to define their legal effects. This margin has to be filled by national law. Moreover the Convention (like all of its preceding conventions ${ }^{32}$ ) shows respect for the autonomy of higher education institutions and therefore does explicitly not impose obligations on them but only on the signatory states with the proviso to implement them without violating the autonomy or freedoms of higher education institutions. Therefore it can be referred to Consideration $6^{33}$ and even more to Art. II.1 p. 1 Lisbon Recognition Convention: Whenever the decision in recognition matters lies with individual higher education institutions (which for academic recognition is the case in almost all European countries), the latter only obliges the Party to transmit the text of the Convention and to take all possible steps to encourage the favourable consideration and application of its provisions. Consequently the provisions of the Lisbon Recognition Convention concerning academic recognition are not directly applicable and need implementation through national law.

Therefore we can conclude that in the field of academic recognition directly binding provisions can only be found in national law.

\footnotetext{
${ }^{30}$ See e.g. OVG Münster, Urt. v. 20.6.2017, Az. 14 A 1776/16, NWVBI. 2017, 534.

${ }^{31}$ See e.g. OVG Berlin-Brandenburg, Beschl. v. 26.9.2012, Az. 10 M 33.11 - juris.

${ }^{32}$ For some examples see fn. Fehler! Textmarke nicht definiert..

${ }^{33}$ It states: "The Parties to this Convention ... attaching great importance to the principle of institutional autonomy, and conscious of the need to uphold and protect this principle ...have agreed as follows:..."
} 


\section{Provisions concerning recognition for the purpose of (self-)employment (Professional Recognition)}

We will now turn our attention to the legal sources that are relevant for professional recognition:
a) European Union Law

aa) EU citizens

On the basis of Articles 46, 53 and 62 TFEU, Parliament and Council have issued the Directive $2005 / 36 / E C^{34}$ on the recognition of professional qualifications.

This directive applies to EU citizens who seek recognition for qualifications which are necessary to take up or pursue a regulated profession in another Member State.

For five academic and one nonacademic professions (doctors, nurses responsible for general care, dental practitioners, veterinary surgeons, pharmacists, architects) the directive formulates minimum standards for professional training and combines that with the introduction of the principle of automatic recognition. That means that recognition has to take place without any (further) check of equivalence or similarity, if the claimants qualification actually fulfills the requirements laid down in the directive (see Art. 21) ${ }^{35}$.

For all other regulated academic and nonacademic professions each Member State is obliged to offer a procedure that leads to recognition under the same conditions that apply to its nationals (Art. 13). That means that a qualification has to be recognized, when it is equivalent to the necessary qualification issued in the host state. If there are substantial differences, the host state must open the way to compensate them through either completing an adaption period (of up to three years) or passing an aptitude test ${ }^{36}$.

This directive is accompanied by the general provisions conferring the right to equal treatment, which were already mentioned above: Art. $24 \mathrm{CRD}$ in cases of legal residence in another Member State; Art. 18 TFEU and Art. 21 II EUChFR, which both

\footnotetext{
${ }^{34}$ Directive 2005/36/EEC of the European Parliament and of the Council of 7 September 2005 on the recognition of professional qualifications, OJ L 255, 30.9.2005, pp. 22-142. For further information and reflection about this directive see e.g. Ludwig, Der europarechtliche Einfluss auf die Entwicklung des nationalen Heilberuferechts, 2018, pp. 139 seq.; Waschkau, EU-Dienstleistungsrichtlinie und Berufsanerkennungsrichtlinie: Analyse der Auswirkungen auf das Recht der freien Berufe in Deutschland unter besonderer Berücksichtigung der Rechtsanwälte, Steuerberater und Wirtschaftsprüfer, 2008, pp. 72-104; Frenz, Die

Berufsanerkennungsrichtlinie und verbliebene sektorale Richtlinien, GewArch 2011, pp. 377-384; Tomkin, in: Kellerbauer/Klamert/Tomkin (eds.), The EU Treaties and the Charter of Fundamental Rights, 2019, Art. 53 comment 9-16 (short summary of its content).

${ }^{35}$ For further details (which also address the profession of a midwife in Art. 40-43) see Art. 21-49.

${ }^{36}$ For specification of these - here simplified - guidelines see Art. 10-14 Directive 2005/36/EEC. German federal law transposes them through the Statute concerning the Assessment of Equivalence of Professional Qualifications (Gesetz über die Feststellung der Gleichwertigkeit von Berufsqualifikationen) of the 6th of December 2011 (especially its §§ 9-13).
} 
will be usually applicable as professional recognition is, as we have seen, widely regulated through EU law.

\section{bb) Third country nationals}

Third country nationals also enjoy the right to equal treatment in certain circumstances defined in Directive 2003/109/EC, the already mentioned "Long-term-Residence Directive". According to its Art. 11, persons with the right to long-term residence have to be treated like nationals inter alia in case of recognition of professional qualifications ${ }^{37}$.

b) International law

Approaching the field of international law we have already seen that professional recognition is not determined through the provisions of the Lisbon Recognition Convention ${ }^{38}$. Therefore, international law with a comparable scope does not exist.

c) National law

As a result we can note that in the field of professional recognition directly binding provisions are also basically found in national law. But unlike national law concerning academic recognition it is not only determined by international law, which can be violated by the parties without provoking a certain effect within national law. In the field of regulated professions, national law is widely determined through EU law (especially Directive 2005/36/EC) whose provisions influence the interpretation of national law and can have direct effect if they are not transposed correctly.

\section{Selective difficulties in the implementation of the rules concerning academic recognition from the perspective of German law}

Considering the given legal framework, this paragraph will illustrate some reasons why currently recognition practice still "falls short of expectations", as the 2018 Bologna Report states. It will concentrate on the field of academic recognition, as therein - in default of any harmonization through EU law - the obstacles to "automatic" or even "broad" recognition are bigger. To identify at least some of them we will take a look at the implementation of the rules presented in chapter I. 1. in Germany, which is due to its size, population and corresponding number of higher education institutions a relevant factor within the EHEA ${ }^{39}$. The reasons for shortcomings in implementation in other states might be different, or elsewhere maybe even similar.

\footnotetext{
${ }^{37}$ To the dispute whether, in addition, Art. 21 II EUChFR is pertinent (within its scope described in Art. 51 EUChFR), see fn. Fehler! Textmarke nicht definiert.

${ }^{38}$ See above I. 1. b).

${ }^{39}$ Concerning the number of students enrolled it takes the third place after Russia and Turkey, see Figure 1.1 Bologna Process Implementation Report (fn. Fehler! Textmarke nicht definiert.), p. 23.
} 
According to an analysis documented in the 2018 Bologna Report Germany is among 18 (from in total 47) EHEA countries which specified all 5 key principles of the Lisbon Recognition Convention in national law ${ }^{40}$. As those key prinicples the analysis identifies (correctly) that

1) applicants have right to fair assessment,

2) there is recognition if no substantial differences can be proven,

3) legislation or guidelines encourage comparing of learning outcomes rather than program contents,

4 ) in cases of negative decisions the competent recognition authority demonstrates the existence of substantial difference, and the

5) applicant's right to appeal.

Actually all these principles are either by means of law or by means of guidelines acknowledged in the German recognition practice. Still, the German recognition practice cannot be described as a practice of completely or almost "automatic recognition" and has problems to ensure transparency, coherence and reliability as demanded through Art. III.2 Lisbon Recognition Convention.

A closer look at the German situation reveals at least some reasons for these deficiencies:

\section{The implementation of the Lisbon Recognition Convention through regulations of the Länder and higher education institutions}

In Germany, being a federal state, legislative power concerning institutions of higher education falls within the competences of the 16 Länder (German constituent states). All of them offer a somewhat differing legal framework that has to be filled in by regulations of higher education institutions, which enjoy the power to regulate their own matters as part of their "academic freedom" guaranteed in Art. 5 III of the German constitution. Most, although still not all, Statutes of the German Länder dealing with academic recognition have modified the wording of the relevant provisions by adopting the "Lisbon terminology": they no longer demand "equivalence" but offer recognition "despite substantial differences are given" 41 . Some of them specify that "substantial differences" hindering recognition must affect "knowledge and skills" certified with a certain qualification, that means they must affect the "learning outcome". An example is $\S 63 a$ of the North Rhine Westfalian Statute on Higher Education Institutions, which states in paragraph 1: "Examinations that have been passed in courses of study at another state or state approved academy (in Germany) as well as examinations that

\footnotetext{
${ }^{40}$ Figure 4.14, Bologna Process Implementation Report (fn. Fehler! Textmarke nicht definiert.), p. 144.

${ }^{41}$ There are still exceptions: E.g. § 23a I 1 of the Berlin Statute on Higher Education Institutions (according to which "comparable" qualifications have to be recognized) or the Statute on Higher Education Institutions of Mecklenburg-West Pomeria (which fully delegates the definition of criteria for recognition to the regulations of the Higher Education Institutions, see $\S 38$ II Nr. 8).
} 
have been passed in courses of study offered by a foreign state or state approved academy will be recognized upon request despite the competences obtained differ substantially from those that shall be substituted." In 2019 there was appended: "an assessment of equivalence will not take place"42. S. 2 and 3 complete: "2The same applies to final degrees that complete courses of study in the sense of $\mathrm{s} .1 .^{3}$ Recognition in the sense of s. 1 and 2 aims at pursuance of further studies, passing of examinations, the take up of another course of study or access to doctoral studies. $(\ldots)^{\prime \prime 3}$

However, the respective statutory law of the Länder usually does not specify when "substantial differences" are given. They abstain from that in order to safeguard the autonomy of higher education institutions, which in Germany, like in the vast majority of the EHEA countries ${ }^{44}$, are the competent authorities for academic recognition ${ }^{45}$.

As a consequence, precise criteria for recognition have to be taken from the regulations of higher education institutions. These regulations on recognition vary significantly in content and terminology - a fact that renders them sometimes difficult to handle. Not all of those regulations specify the "Lisbon Standard" at all. Some of them abstain completely from specification and merely repeat the wording of the Länder legislation. An example is $\S 15$ of the General Examination Regulation for Bachelor and Master Studies at the Faculty of Philosophy at the Frederick Alexander University ErlangenNuremberg ${ }^{46}$, which states: "Periods of study and qualifications that have been achieved in courses of study at another state or state approved academy in Germany (...) or qualifications that have been achieved in courses of study offered by a foreign

\footnotetext{
42 Thereby the legislator indicates that there is a difference between "equivalence" and "lack of substantial difference" (to that question see more in fn. Fehler! Textmarke nicht definiert.). Against this approach Birnbaum, in: BeckOK HochschulR NRW, 13. Ed. 1.12.2019, § 63a Rn. 23b, who regards the two parts of s. 1 to be a contradictio in adiecto.

${ }^{43}$ Free translation of the original text: ", 1 Prüfungsleistungen, die in Studiengängen an anderen staatlichen oder staatlich anerkannten Hochschulen, an staatlichen oder staatlich anerkannten Berufsakademien, in Studiengängen an ausländischen staatlichen oder staatlich anerkannten Hochschulen oder in einem anderen Studiengang derselben Hochschule erbracht worden sind, werden auf Antrag anerkannt, sofern hinsichtlich der erworbenen Kompetenzen kein wesentlicher Unterschied zu den Leistungen besteht, die ersetzt werden; eine Prüfung der Gleichwertigkeit findet nicht statt. ${ }^{2}$ Das Gleiche gilt hinsichtlich Studienabschlüssen, mit denen Studiengänge im Sinne des Satzes 1 abgeschlossen worden sind. ${ }^{3}$ Die Anerkennung im Sinne der Sätze 1 und 2 dient der Fortsetzung des Studiums, dem Ablegen von Prüfungen, der Aufnahme eines weiteren Studiums oder der Zulassung zur Promotion."

${ }^{44}$ See Figure 4.15, Bologna Process Implementation Report (fn. Fehler! Textmarke nicht definiert.), p. 145.

${ }^{45}$ Only for study programms which are completated by a stateexaminiation the competence for recognition lies with the respective state examination authorities.

${ }^{46}$ Allgemeine Studien- und Prüfungsordnung für die Bachelor- und Masterstudiengänge der Philosophischen Fakultät und Fachbereich Theologie der Friedrich-Alexander-Universität Erlangen-Nürnberg of the 27th of September 2007, lastly changed at the 28th of August 2019.

www.doc.zuv.fau.de//L1/PO/Phil/APO_Bachelor_Master/konsolidierte_Fassungen/Allg_StuO_PrO_\%20BAMA \%20Phil ABMStPO Phil 20070927 idF 20190828.pdf (15.2.2020).
} 


\section{academy will be (...) recognized despite the learning outcomes are substantially different." 47}

Others formulate a definition which does not fully live up to its purpose. This is for example the case when the Examination Regulation for Bachelor and Master Studies at the University of Göttingen explains that "a substantial difference is at least not given, if (the qualification) (...) substantially corresponds to the qualification it shall substitute" 48 .

None of the regulations that were checked for the preparation of this article took over the (however not legally binding) specifications of "substantial differences" proposed in documents published by the Council of Europe and in the relevant Manual issued by the Hochschulrektorenkonferenz $\mathrm{z}^{49}$ : They did not adopt that - according to the Lisbon Recognition Convention Committee - only those differences can justify the denial of recognition which are "substantial in view of the purpose for which recognition

\footnotetext{
${ }^{47}$ Free translation of the original wording: ${ }^{1}$ Studienzeiten, Module, Studienleistungen und Prüfungsleistungen, die in anderen Studiengängen an der FAU oder an anderen staatlichen oder staatlich anerkannten Hochschulen in der Bundesrepublik Deutschland (...) oder in Studiengängen an einer ausländischen Hochschule erbracht worden sind, werden bei einem Studium nach dieser Prüfungsordnung anerkannt, außer es bestehen wesentliche Unterschiede hinsichtlich der erworbenen Kompetenzen.

${ }^{48}$ Free translation of the original wording in § 13 IV 1, 2 Allgemeine Prüfungsordnung für Bachelor- und MasterStudiengänge sowie sonstige Studiengänge an der Universität Göttingen, Stand: AM I Nr. 54 v. 9.11.2017: "1Studienzeiten, Studien- und Prüfungsleistungen beziehungsweise Kompetenzen, die in anderen Studiengängen oder außerhalb einer Hochschule erbracht wurden, werden auf Antrag angerechnet, soweit kein wesentlicher Unterschied gegenüber den Kompetenzen, die im Falle eines Studiums an der Universität Göttingen erworben worden wären, festgestellt werden kann; (...) ${ }^{2}$ Kein wesentlicher Unterschied besteht jedenfalls, wenn die auf Grund eines Moduls vermittelten Kompetenzen beziehungsweise Lernergebnisse, Qualität und Niveau der Ausbildung sowie Anrechnungspunkte denjenigen von Modulen des Studiengangs im Wesentlichen entsprechen. " Other regulations of higher education institutions try to define the recognition criteria more precisely, but might thereby fail to meet the requirements of the Lisbon Recognition Convention. An example is the Examination Regulation for the Bachelor in History at the Ludwig-Maximilians-University in Munich (Prüfungs- und Studienordnung der Ludwig-Maximilians-Universität München für den Bachelorstudiengang Geschichte v. 16.3.2010, https://www.uni-muenchen.de/aktuelles/amtl voe/0400/49309ge-ba-10-ps00.pdf (15.2.2020)), which states in § $26 \mathrm{III}, \mathrm{IV}$ : “Qualifications achieved at foreign academies will be normally recognized besides they are not equivalent. Qualifications are equivalent when they essentially conform to the local course of study in content, quantity and in its demands.” (in German: „(3) Studienzeiten, Studien- und Prüfungsleistungen, die an ausländischen Hochschulen erbracht worden sind, werden in der Regel anerkannt, außer sie sind nicht gleichwertig. (4) ${ }^{1}$ Studienzeiten, Studien- und Prüfungsleistungen sind gleichwertig, wenn sie in Inhalt, Umfang und in den Anforderungen denjenigen dieses Bachelorstudiengangs an der Ludwig-Maximilians-Universität München im Wesentlichen entsprechen“.) This provision adopts the Lisbon Recognition Convention insofar as it confers the burden of proof to the recognizing authority. However, as criterion for recognition it requires "equivalence" in "content, quantity and demand". This might contravene the intention of the Lisbon Recognition Convention outlined above, at least when it leads to an restrictive understanding of "equivalence“.

${ }^{49}$ Hochschulrektorenkonferenz (ed.), Anerkennung (fn. Fehler! Textmarke nicht definiert.), p. 25. It resumes: The crucial question in the assessment of given (potentially "substantial") differences is whether the qualification achieved in a foreign country will enable the student to pursue his or her studies sucessfully. Only when the sucess of subsequent studies is doubtful, a "substantial" difference can be approved.
} 
is sought" 50 . And none of them took over the even more precise and far-reaching specifications referred by the Manual of the Hochschulrektorenkonferenz, that "essentially, substantial differences are (only) those that may have a serious impact on the fitness of the qualification for the purpose for which the learner would like to use it" ${ }^{\text {"51 }}$ and that "substantial differences are differences between the foreign qualification and the national qualification that are so significant that they would most likely prevent the applicant from succeeding in the desired activity such as further study, research activity $(\ldots)^{n} 52$.

If the criteria for recognition are not defined precisely, decisions are only predictable for the applicant in cases in which special agreements on equivalence exist (i.e. in partnerships of individual higher education institutions). In other cases, decisions remain fairly intransparent and as a consequence of their unclear scale, not very reliable.

Therefore we can note that one obstacle for fair recognition in Germany is that at least some higher education institutions do not offer a precise definition of recognition criteria complying with the requirements of the Lisbon Recognition Convention ${ }^{53}$.

\section{Specification of recognition criteria in current jurisdiction}

Of even bigger relevance might be that the term "lack of substantial differences" has recently been specified in jurisdiction. Thereby the courts did not only identify "lack of substantial difference" with "equivalence" (which might barely comply with the Lisbon Recognition Convention if "equivalence" is interpreted in an appropriate way ${ }^{54}$ ). Moreover, they defined "equivalence" through specifications that contravene not only the intention but also the wording of the Lisbon Recognition Convention ${ }^{55}$ : in 2017 the OVG Münster, the Higher Administrative Court of North Rhine Westfalia, ${ }^{56}$ had to rule on whether a Czech student can demand recognition for her master's thesis, prepared

\footnotetext{
${ }^{50}$ See Lisbon Recognition Convention Committee, Revised Recommendation on Criteria and Procedures for the Assessmet of Foreign Qualifications, adopted at its 5th meeting, 23. June 2010; Recommendation No. 36.

${ }^{51}$ Hochschulrektorenkonferenz (ed.), Anerkennung (fn. Fehler! Textmarke nicht definiert.), p. 25, taken from Bergan/Hunt (eds.), Developing Attitudes to Recognition: Substantial Differences in an Age of Globalization. Council of Europe Higher Education Series No. 13, Strasbourg, 2009, p. 9.

52 Hochschulrektorenkonferenz (ed.), Anerkennung (fn. Fehler! Textmarke nicht definiert.), p. 25, taken from Lifelong Learning Programme (ed.), European Area of Recognition Manual. Practical Guidelines for Fair Recognition of Qualifications, p. 42.

${ }^{53}$ Thus not all of them provide what is recommended in III. 6. of the (not legally binding) Revised Recommendation on Procedures and Criteria for the Assessment of Foreign Qualifications and Periods of Study (fn. Fehler! Textmarke nicht definiert.): that “(...) criteria for the assessment of foreign qualifications should be transparent, coherent and reliable and they should periodically be reviewed ...".

${ }^{54}$ See fn. Fehler! Textmarke nicht definiert..

${ }^{55}$ For an extensive debate on this and other aspects of the respective decisions see Morgenroth, Wesentlicher Unterschied oder „der Sache nach erbracht“ - neue Entwicklungen zur Anerkennung von Prüfungsleistungen an staatlichen Hochschulen, DÖD 2018, pp. 177-192.

${ }^{56}$ OVG Münster, Urt. v. 20.6.2017, Az 14 A 1776/16, NWVBI 2017, 534.
} 
and assessed at the Czech University of Life Sciences in Prague. According to the defendant's argumentation before the Court of First Instance (the Administrative Court of Aachen) recognition for the purpose of further education had to be denied since the master's thesis had been prepared in different circumstances and because it has not been written in German or English, which would have been obligatory according to the examination regulation of this course of studies at the German university ${ }^{57}$. The Court of First Instance affirmed that the fact that the claimants master's thesis had not been written in German of English constitutes a "substantial difference"58. In that context, the OVG Münster had to decide whether "substantial differences" in the understanding of $\S 63 a$ North Rhine Westfalian Statute on Higher Education Institutions had been proven. The court declared (according to a preceding decision in 2015 59 ) that substantial differences are only absent when the qualification to be recognized, corresponds to the qualification that is to be substituted in respect of content and quantity of the examinated subject matter and in respect of form and length of the examination. Higher education institutions could only be obliged to recognize a foreign qualification that is so close to the demanded qualification that it could be called "the same in substance" (in German: wenn die Qualifikation „in der Sache erbracht" wurde $)^{60}$. The claimant's master thesis missed that standard as it dealt with a subject the student would not have been able to choose at her new university - as the subject of the master thesis could in general not be chosen freely there. According to the court, this interpretation of the term "lack of substantial differences" is necessary, as otherwise the academic freedom guaranteed within the German constitution (Art. 5 III $\mathrm{GG}$ ) would be violated. The Bundesverwaltungsgericht (BVerwG), the Highest Administrative court in Germany, confirmed this decision in $2018^{61}$ by adding the argument that any more generous standard of recognition would be an unconstitutional discrimination of local students: To safeguard equality of opportunities (guaranteed by Art. 3 I i.V.m. Art. 12 । GG) only those examinations can be recognized that "coincide with regard to content and examination conditions" 62 . It even indicates that it would mean an unconstitutional discrimination of local students if qualifications are recognized that have (only) been formulated in a language which cannot be chosen by

\footnotetext{
${ }^{57}$ VG Aachen Urt. V. 29.6.2016, Az. 6 K 1107/16- juirs, para. 15.

58 lbd. para. 33.

${ }^{59}$ OVG Münster, Urt. v. 16.12.2015 - 14 A 1263/14, DÖV 2016, 353 = NWVBI 2016, 212.

${ }^{60}$ OVG Münster, Urt. v. 20.6.2017, Az 14 A 1776/16 (= NWVBI 2017, 534), para. 36; Urt. v. 16.12.2015 - 14 A

1263/14 (=NWVBI. 2016, 212), para. 23.

${ }^{61}$ BVerwG, Beschl. v. 9.1.2018, Az. 6 B 63/17, NVwZ-RR 2018, 308.

62 Ibid. para. 9, in German: „Daher kommt eine Anerkennung zur Wahrung der Chancengleichheit nach Art. 3 Abs. 1 i.V.m. Art. 12 Abs. 1 GG nur in Betracht, wenn die Studierenden den durch die Prüfung zu erbringenden Nachweis bestimmter Kenntnisse und Fähigkeiten bereits durch die anderweitige Prüfungsleistung erbracht haben. Hierfür müssen beide Prüfungen in Bezug auf Prüfungsstoff und Prüfungsbedingungen übereinstimmen." Therein the BVerwG affirms and strengthens a former decision of the 22. of June 2016, Az. 6 B 21/16 (= NVwZ-RR 2016, 783), especially para. 13-15.
} 
local students, as those have to stick to the languages offered by the examination regulation of their university ${ }^{63}$.

When interpreting the law of North Rhine Westfalia, the OVG Münster did not mention the Lisbon Recognition Convention as background of the reformulated scale for recognition decisions in present legislation (which took the place of $\S 20 \mathrm{HRG}$, that demanded the acknowledgment of "equivalence"). It did not question whether the purpose of $\S 63 a$ NRWHG or its background in international law argued for an interpretation that coincides with the intention of the Lisbon Recognition Convention. And neither the OVG Münster nor the Bundesverwaltungsgericht mentioned Art. 24 CRD or Art. 18 TFEU, although the claimant being an EU citizen residing in a host Member State and the denial of recognition because an exam was passed in a foreign language could be an indirect discrimination due to nationality.

It is highly doubtful, whether more generous recognition obligations actually violate the German constitution. It is not possible to reflect about this in detail64 here. However, the author is convinced that in the end this is not the case, e.g. as "disadvantages" for local students can be justified through the purpose of recognition, which lies in reducing disadvantages that necessarily occur with any movement between different higher education institutions, especially across national borders and under the circumstance of wide academic freedom which leads to significant differences in study programs and higher education qualifications (in order to benefit from the advantages of mobility within and across national borders, as are inter alia the widening of the students perspective on their subject and the world in general or the promotion of international understanding $)^{65}$.

Furthermore the decisions can be criticized due to their complete ignorance of international law: 1) The OVG Münster interpreted § 63a NRWHG without mentioning its background in international law, although German legal scholarship ${ }^{66}$ and case

\footnotetext{
${ }^{63}$ BVerwG, Beschl. v. 9.1.2018, Az. 6 B 63/17 (= NVwZ-RR 2018, 308), para. 12.

${ }^{64}$ For a detailled discussion see Morgenroth (fn. Fehler! Textmarke nicht definiert.), pp. 183 seq.

${ }^{65}$ In fact - in reverse - disadvantages of mobile students require fair recognition and every denial of recognition must be justified as it refuses compensation of those disadvantages. Concerning academic freedom one has to answer whether the legal obligation to recognize qualifications which are in a certain way comparable to those required by the higher education institution itself acutally means an enchroachment upon academic freedom. Concerning this matter the Constitutional Court of Germany (BVerfG) not only stated that the competence to pass examination regulations is protected by the fundamental right of academic freedom but also that „the organisation of scientific organisations - including regulations on teaching and examination is in principle left to the legislator" („die Ausgestaltung von Wissenschaftsorganisationen einschließlich des Lehr- und Prüfungsrechts (ist) grundsätzlich dem Gesetzgeber überlassen“, see BVerfG v. 26.6.2015, DÖV 2015, 888 (889, para. 19)).

${ }^{66}$ See e.g. Tomuschat, Entscheidung für internationale Offenheit, in: Isensee/Kirchhof (eds.), Handbuch des Staatsrechts, Vol. XI, 3rd ed., 2013, § 226 comment 36; Hofmann, Der Grundsatz der völkerrechtsfreundlichen Auslegung, JURA 2013, pp. 326-333.
} 
law $^{67}$ has established a principle called "völkerrechtsfreundliche Auslegung"68. It demands that when the interpretation of a provision is doubtful, an interpretation in accordance with (the transposed) international law has to be chosen, as long as it is feasible. 2) The decision of the BVerwG indicates that it could or would be a violation of the German constitution if qualifications passed in a foreign language are recognized. This principle cannot be formulated without asking the question whether it complies with Art. 24 I CRD ${ }^{69}$ (which finally must be answered by the CJEU):

Art. 24 I CRD in principle does not only prohibit direct but also indirect discrimination because of nationality. The understanding that the use of a language different from the language of instruction at the host university constitutes a "substantial difference" between qualifications in itself can be perceived as an indirect discrimination due to nationality, as qualifications in other Member States, which are typically achieved by the nationals of those states, are typically demanded in the official language of this Member State (or in English, however not in all other official languages of the EU).

Therefore we have to answer the question whether this kind of indirect discrimination can be justified ${ }^{70}$. It is assumed that (in general) justification fails: In most academic studies the qualifications that have to be obtained do not depend on the language in which they have been presented. Insofar, a certain language is not essential for that qualification (exceptions are possible, for example when in studies of law it is a key competence to be able to understand and use a certain language). Besides, one has to keep in mind, that the proof of whether the applicants German is good enough to follow further studies in German (which could be the case although he or she passed exams in a foreign language) is necessary irrespective of the recognition of certain qualifications. Sufficient language skills are an independent, in general justifiable criterion for the mere access to a German university. It is therefore neither necessary, nor reasonable to combine the recognition decision with the proof, if the applicants German is good enough to follow further studies in German ${ }^{71}$.

\footnotetext{
${ }^{67}$ See e.g. BVerfGE 58, 1 (34); 74, 358 (370); BVerfG, Nichtannahmebeschl. v. 28.9.2006, Az. 2 BvR 1731/04 juris, Rn. 7-13; BVerwGE 75, 285 (288); Hessisches Landessozialgericht, Urt. v. 24.11.2010, Az. L 6 AS 168/08 juris (= EuG 2011, 332-342), para. 36.

${ }^{68}$ This instrument, the "völkerrechtsfreundliche Auslegung", must not be perceived as a method of interpreting law which is added to the methods commonly acknowledged. It can also - or even better - be perceived as a term to describe the systematic and teleological interpretion of laws which were established to transpose international law.

${ }^{69}$ Or in cases in which the applicant does not reside in a host state: with Art. 18 TFEU.

${ }^{70}$ To the possibility to justify discriminations generally prohibited by Art. 18 TFEU see e.g. Epiney, in: Calliess/Ruffert (eds.), EUV/AEUV, 5th ed., 2016, comment 37 with reference to relevant jurisdiction of the CJEU. We assume that theses principles can be transferred when interpreting Art. 24 CRD.

${ }^{71}$ Insofar the decisions discussed here might be regarded as an example for the conflation of the decision on whether to admit or not to admit a student with the decision about whether to recognize a particular qualification, which the 2018 Bologna Process Implementation Report (fn. Fehler! Textmarke nicht definiert.), p. 142, named as one of the main prevailing obstacles for broad recognition. The arguments presented above
} 


\section{Conclusion}

Those findings lead to the following conclusion: Even the implementation in German law which was positively evaluated within the 2018 Bologna Report falls short of the demands of the Lisbon Recognition Convention in different respects:

It does, at least partially, not provide precise, reliable criteria for the lack of "substantial differences".

And at least according to the prevailing case law it allows recognition only in cases of strict "equivalence" (by denying equivalence with arguments that conflict with EU law). This is of great importance as in the end it will be the national courts deciding on conflicts about granting recognition.

From that, we can see that already better knowledge and better consideration of the existing international law could help to enhance recognition. Especially EU law, even its guarantees of equal treatment, can foster recognition, as it has supremacy over national law and can be enforced through the bodies of the EU, mainly through the CJEU. Therefore, professional recognition is easier to enforce than academic recognition (which is less determined by EU law).

But that does not mean that there is nothing left to do:

From the German perspective in some Länder a more precise formulation of recognition standards in statutory law would help. In addition, it is useful that within the process of assessment of higher education institutions instruments are established to secure that higher education institutions formulate precise and lawful criteria for recognition ${ }^{72}$, because without precise criteria predictable, reliable decisions cannot be reached.

\section{Zusammenfassung:}

Der Artikel gibt einen Überblick über die rechtlichen Regeln, die innerhalb der EU und des Europäischen Hochschulraums für die Anerkennung von Hochschulleistungen gelten. Dabei muss zwischen der Anerkennung für die Zwecke der Erwerbstätigkeit

do not exclude that in certain cases an applicant can be required to offer a (whole oder partial) translation of his examination work if this is necessary to assess whether substantial differences are given or not.

72 This has already been put into practice: According to the Rules on Accredition of Courses of Study and Systems (Regeln für die Akkreditierung von Studiengängen und für die Systemakkreditierung, Stand: 20.2.2013, https://www.akkreditierungsrat.de/sites/default/files/downloads/2019/AR Beschluss Regeln Studiengaenge Systemakkreditierung 2013.02.20 Drs.20-2013.pdf (15.2.2020), p. 11), issued by the German Accreditation Council, the concept of a course of study has to formulate rules for the recognition of foreign qualifications that comply with the Lisbon Recognition Convention (free translation of the German wording: „(Das

Studiengangkonzept) legt die Zugangsvoraussetzungen (...) fest sowie Anerkennungsregeln für an anderen Hochschulen erbrachte Leistungen gemäß der Lissabon Konvention ...“.). However, provisions like this can only be applied appropriately if it is clarified what kind of rules are required by the Lisbon Recognition Convention. 
und für die Fortführung eines Studiums unterschieden werden. Nach der Einführung in die Rechtslage wendet sich der Artikel den Problemen zu, die bei der Anerkennung für die Fortführung eines Studiums auftreten können, da diese in der Praxis auf größere Hindernisse treffen kann, weil es an einer Harmonisierung durch EU-Recht fehlt. Zu diesem Zweck untersucht er die Umsetzung der internationalrechtlichen Vorgaben der sog. „Lissabon Konvention” (die unter allen für Deutschland gegenwärtig geltenden Anerkennungsabkommen den weitesten Anwendungsbereich hat) in das deutsche Recht. Dabei prüft er das einschlägige Landesrecht und verschiedene, beispielhaft ausgewählte Hochschulsatzungen darauf, ob und inwiefern sie die Vorgaben der Lissabon-Konvention umsetzen, nach der eine Hochschulleistung anzuerkennen ist, wenn nicht "wesentliche Unterschiede” zu der sie ersetzenden Leistung nachgewiesen werden können. Anschließend prüft er die jüngst hierzu ergangene Rechtsprechung (insbes. BVerwG, Beschl. v. 9.1.2018, NVwZ-RR 2018, 333) darauf, ob sie den Vorgaben der Lissabon-Konvention zur Durchsetzung verhilft. Dabei kommt er zu dem Ergebnis, dass sie die Vorgaben der Lissabon-Konvention konterkariert (indem sie eine Anerkennung nur für zulässig erklärt, wenn die zu ersetzende Leistung „in der Sache erbracht” wurde bzw. beide Leistungen „in Bezug auf Prüfungsstoff und Prüfungsbedingungen übereinstimmen") und sich außerdem in ihrer konkreten Begründung zu einschlägigem Unionsrecht in Widerspruch setzt.

\section{About the author:}

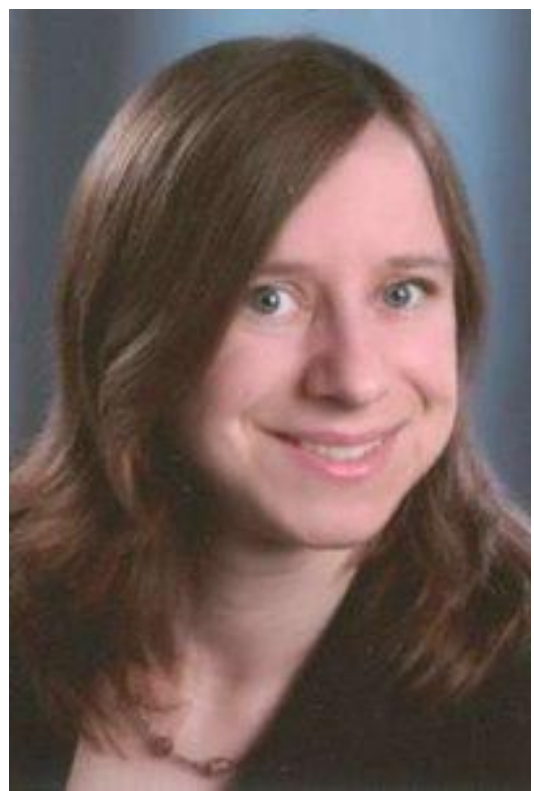

Renate Penßel is Research Assistant at the Chair of Ecclesiastical Law, Constitutional and Administrative Law (Prof. Heinrich de Wall) at the Friedrich-AlexanderUniversity Erlangen-Nürnberg. Her research focuses on Protestant Ecclesiastical Law, Law concerning Religion and Religious Communities (in past and present) and on Higher Education Law. 